\title{
Acho que já começa errado daí, ninguém é preso, ele está preso!
}

\author{
Samara Feitosa ${ }^{1}$
}

Resumo: Entre abril de 2011 e setembro 2012, frequentei as filas de visitantes de duas unidades do Complexo Penal de Piraquara (PCE - Penitenciária Central do Estado e PFP - Penitenciária Feminina do Paraná), meu objetivo era, naquele momento, entrar em contato com familiares de presos e presas para tentar compreender quais estratégias essas famílias desenvolviam na busca da manutenção dos laços familiares; o resultado dessa pesquisa deu origem ao texto de tese defendida no doutorado em abril de 2013. Nesse ensaio busco retomar algumas das entrevistas e conversas com o corpo técnico dessa unidade tentando perceber com quais representações acerca dos internos e seus familiares os mesmos operavam.

Palavras-chaves: Sistema penitenciário, Representações sociais, Corpo técnico.

\section{I think it starts wrong from there, no one is arrested, he is arrested!}

\begin{abstract}
Between April of 2011 and September 2012, I frequented the visitors' lines of two unities of the Penal Complex of Piraquara (PCE - Central Prison of the State and PFP - Feminine Prison of the Paraná), my objective was, in that moment, to get in touch with relatives of prisoners to try to understand which strategies these families were developing in the search of the maintenance of the familiar knots, the result of this inquiry gave rise to the text of theory defended in the doctorate in April of 2013. In this essay I look to retake some of the interviews and conversations with the technical staff of these units trying to perceive with which representations about the interns and their families these technicians operated.
\end{abstract}

Key words: penitentiary system. social representations. technical staff

\section{Como chegamos até aqui}

Entender a constituição do sistema penitenciário passa antes pela compreensão da existência da punição nas sociedades, entretanto é necessário pensar a mesma não em uma relação intrínseca ao crime cometido, mas ligada a um determinado momento histórico e político. Vale lembrar aqui do que nos diz Durkheim a respeito do crime. Para ele não há, a princípio, algo que possa ser designado, a qualquer tempo e espaço, como ato criminoso, sendo assim, cada grupo social poderá pensar práticas diversas como atos

\footnotetext{
${ }^{1}$ Doutora em Sociologia e pesquisadora do CESPDH (Centro de Estudos e Segurança Pública e Direitos Humanos da UFPR).
} 
Revista NEP, Núcleo de Estudos Paranaenses, Curitiba, v.4, n.2, dez. 2018

criminosos. Para este autor, o que tais atos têm em comum é o fato de que ferem os sentimentos coletivos destes grupos, levando-os a constituírem sanções aos que os comete. Por isso mesmo, o autor irá criticar as abordagens que vinham sendo feitas acerca do tema considerando-as “in abstrato”. Para ele, o crime, a punição e suas instituições só poderiam ser compreendidos quando fossem levadas em consideração as relações e interações sociais que as permeiam. (DURKHEIM, 1973)

Por este olhar é possível, então, relacionar o nascimento e a ascensão da pena de privação de liberdade ao seu contexto originário, qual seja o desenvolvimento do capitalismo.

Michel Foucault (1999) afirma que no período que antecede o desenvolvimento do capitalismo a ideia de punição tem como alvo o corpo do indivíduo. A capacidade de infligir dor, o sofrimento físico e a exposição pública dos rituais punitivos marcam este período.

Aos poucos, com o desenvolvimento do capitalismo, dá-se uma nova inflexão nas estratégias punitivas que pretendem não mais atingir o corpo dos apenados, por meio dos chamados suplícios, mas sua alma. Foucault afirma que as penas ligadas aos suplícios passam a ser identificadas como uma forma de barbárie e que precisam, portanto, passar por transformações para que se tornem compatíveis com o patamar de desenvolvimento da racionalidade do período. Além disto, é preciso também alterar a percepção que se tinha a época, acerca da punição que, segundo o autor, acabava igualando juízes, carrascos e criminosos, isso porque utilizavam na punição um grau de perversão e barbárie muito próximo ao usado nos próprios crimes. (Foucault, 1999). Tem início o que o autor denomina de disciplinarização da sociedade que atuará, principalmente, sobre os corpos (agora não mais no sentido de lhe infligir dor, mas na busca de sua domesticação) haja vista sua importância fundamental ao novo sistema produtivo que se estabelecia. Embora tenha claro que as disciplinas não foram inventadas pelo sistema capitalista, Foucault afirma que este se apropriará das mesmas, efetuando os devidos ajustes para que elas viabilizem o desenvolvimento do sistema capitalista, principalmente, no que concerne às relações de dominação intrínsecas ao antagonismo existente na relação capital e trabalho.

Se a sociedade como um todo é atingida por esta disciplinarização, as classes consideradas perigosas serão seu alvo favorito. Para este autor, assiste-se, a partir do século XVII, a um processo de perseguição a pobreza e a mendicância que visa consolidar 
Revista NEP, Núcleo de Estudos Paranaenses, Curitiba, v.4, n.2, dez. 2018

os novos padrões morais alicerçados sobre o trabalho e a prosperidade. Exemplo disto é o fenômeno da grande internação onde, segundo Foucault (1997), aproximadamente 1\% da população parisiense se encontra confinada em asilos, casas correcionais ou hospitais, numa busca profilática de manutenção da ordem pela reclusão da pobreza em espaços que passam a ser considerados, cada vez mais, como seus de direito. $\mathrm{O}$ autor afirma ainda que se fez necessária a criação de uma identidade negativa para os indivíduos que não agiam de acordo com os novos parâmetros de moralidade que estavam se constituindo, já que, em muitos momentos, era perceptível certa simpatia por parte da população em geral para com estes indivíduos: (FOUCAULT, 2006). Entretanto, a pena de privação de liberdade ${ }^{2}$, encontrará sua completa realização material com a consolidação da sociedade industrial dos séculos XVIII e XIX, que aliada ao desenvolvimento de uma racionalidade iluminista, configura uma modalidade moderna de punição.

Moraes (2005) afirma que seu surgimento será - de certa forma - resultado de um longo processo de transformações sociais que vinham sendo desenhado já há algum tempo (por meio dos eventos que constituem a modernidade) e atinge a sociedade como um todo

Tudo indica que a prisão aparece também como uma forma de substituição do suplício e da tortura, uma forma de castigo supostamente mais humano e mais fácil de ser dosado, atendendo às exigências de vários pensadores e juristas por uma "justa medida" no momento de punição. Tais motivos é que nos levarão a estabelecer uma correlação entre o encarceramento e o "ideal reabilitativo". Essa questão nos aproxima também, do processo de racionalização que poderia, inclusive, ser rentável monetariamente. (MORAES, 2005: 133)

O tom do discurso de reforma pensado para o sistema punitivo, segundo Foucault, é dado pelo deslocamento das ações criminosas que passam a não incidir mais na violência contra a pessoa, mas têm como alvo preferencial a propriedade privada. Somado a isto, acionam-se mecanismos que procuram introduzir uma nova economia política para as penas, substituindo-se a pena de execução pelo pagamento de fianças e

\footnotetext{
${ }^{2}$ Há que se notar que antes do nascimento da prisão moderna o encarceramento não era desconhecido da sociedade, o mesmo tinha, entretanto, características e objetivos diferenciados. A prisão era um lugar de confinamento para os indivíduos que esperavam pela punição. Outro ponto diferenciador diz respeito ao fato de que não se esperava que ao sair dele os indivíduos tivessem sido recuperados para o convívio em sociedade, não tendo, portanto, nenhum propósito ou finalidade moralizadora como tinham, por exemplo, os suplícios.
} 
multas que protegeriam os bens, o encarceramento só seria utilizado como último recurso para quem não pudesse pagar o preço estabelecido; a punição estaria centrada, então, na retribuição do dano e em sua proporcionalidade.

Contudo a prisão, em sua carreira de ascensão, altera esta lógica. A pena passa a ser estabelecida não mais por efeito de ações concretas dos indivíduos, mas em sua potencialidade; estabelecem-se padrões de periculosidade que interferem na correção dos indivíduos e nas suas possíveis ações criminosas (FOUCAULT, 2006). Esta alteração na trajetória do sistema punitivo está ligada à necessidade urgente da criação de mecanismos que garantissem a consolidação do capitalismo. A vigilância passa a ser o ponto fundamental para o qual a burguesia mobiliza suas energias, tendo a disciplina como centro. A prisão como principal elemento punitivo torna-se, então, paradigmática desta nova ordem que se estabeleceu, mas o autor postula que se muito mudou uma parcela de dor ainda persiste:

Permanece, por conseguinte, um fundo "supliciante" nos modernos mecanismos da justiça criminal - fundo que não está inteiramente sob controle, mas envolvido, cada vez mais amplamente, por uma penalidade do incorporal.(FOUCAULT, 1999. ps19,20)

A partir do século XIX, a ideia do encarceramento como elemento basilar da maneira de punir, naturalizou-se e pôde reproduzir-se sem encontrar grande resistência nem mesmo de quem passaria a ser seu alvo principal, ou seja, as classes populares, já que os mecanismos adestradores da sociedade, advindos também de outras esferas da vida social (família, escola, hospitais, fábrica, etc.), asseguravam o reconhecimento de sua necessidade.

Nota-se, entretanto, que ao longo de sua carreira a instituição prisional sofreu mudanças no sentido do ajuste dos mecanismos que utiliza para garantia de sua funcionalidade dentro do sistema social, dispositivos como concessão de benefícios, imposição de obrigações e, até mesmo, a ideia de direitos dos presos, perfazem o caminho trilhado por este tipo de instituição. Todavia é preciso ressaltar que se a função da punição nunca foi excluída de seu ideário, à pena de privação de liberdade foi associada à possibilidade de recuperação dos indivíduos.

A ideia basilar desta nova organização era a de que o isolamento forçado dos 
condenados a reclusão levaria os mesmos a reflexão sobre seus atos e que a sua permanência em instituições que controlavam rigidamente as ações diárias dos indivíduos reclusos, por meio de práticas especificamente orientadas, proporcionaria a incorporação da disciplina necessária à convivência na sociedade, levando, assim, os indivíduos a sua regeneração e preparando-os para o retorno ao convívio social. (MORAES, 2005)

É ainda este autor que ressalta a ligação entre a prisão moderna, as instituições de punição religiosas e a ideia de penitência. Assim, é possível perceber claros sinais da influência da justiça eclesiástica na justiça laica.

\begin{abstract}
É do encontro e articulação entre leis religiosas e seculares que começa a ser gestada a ideia de prisão como forma de punição e ao mesmo tempo de penitência e de correção. A prisão moderna é um híbrido de práticas religiosas penitenciais medievais com o mundo moderno e o processo de laicização, racionalização e eficácia, que estariam longe de uma ruptura com a religiosidade a até mesmo a Igreja Católica que se manteve preservada graças a Revolução Papal, que muito antes de retirar-se dos negócios laicos, criou obstáculos a intervenção secular e seus domínios ao mesmo tempo em que manteve sua influência sobre aquela esfera de poder (BERMAN apud MORAES, 2005.p 138)
\end{abstract}

Sendo assim, a prisão passa a ser pensada como a maneira de punição que teria maiores chances de punir infringindo a medida certa de dor, ao mesmo tempo em que possibilitaria a correção do criminoso já que o afastando do convívio social, isolando da sociedade em geral, permitiria aos indivíduos o tempo necessário para reflexão e arrependimento dos atos cometidos. Não se pode desconhecer, também, o quanto estão presentes neste novo contexto, as transformações advindas da Reforma e do novo ethos protestante que reforçava a ideia do trabalho e da assepsia moral.

Já bastante difundida a prisão passa a ser, cada vez mais, alvo de reflexões e propostas de reforma e, é novamente Foucault (1977) que nos chama a atenção para o fato desta instituição já nascer destinada a reforma, visto buscar conciliar duas funções não tão facilmente compatíveis, quais sejam, a punição (por meio do isolamento da sociedade) e a reabilitação (para o convívio social).Segundo o autor:

Devemos lembrar também que o movimento para reforma as prisões, para controlar seu funcionamento não é um fenômeno tardio. Não parece sequer ter nascido de um atestado de fracasso devidamente lavrado. A "reforma" da 
Revista NEP, Núcleo de Estudos Paranaenses, Curitiba, v.4, n.2, dez. 2018

prisão é mais ou menos contemporânea da própria prisão. Ela é como que seu programa. A prisão se encontrou, desde o início, engajada numa série de mecanismos de acompanhamento, que aparentemente devem corrigi-la, mas que parecem fazer parte de seu próprio funcionamento, de tal modo têm estado ligados a sua existência em todo o decorrer de sua história. (FOUCAULT, 1977.p 209)

Dentre as várias ondas reformistas destacaremos aqui, ainda que rapidamente, dois momentos: as reformas pensadas por John Howard e as propostas por Jeremy Bentham.

John Howard (1726-1790) irá ocupar-se deste tema, ao que parece, após assumir o cargo de responsável pela segurança pública da cidade inglesa de Bedforshire. Tal cargo faz com que o mesmo entre em contato com a realidade das prisões de sua época. Sua orientação religiosa (protestante) faz com que o mesmo perceba tal realidade como desumana, totalmente anticristã e incapaz de cumprir o papel de recuperação social dos indivíduos. Para este reformador, ao qual se imputada o uso, pela primeira vez, do termo penitenciária para tais instituições, a situação na qual se encontram as mesmas - situação que ele aponta como caótica - é fruto da incapacidade administrativa. Howard, entretanto, apostava nela e acreditava que a mesma conseguiria cumprir seus propósitos desde que passasse por mudanças. Segundo Gonçalves (2009) vigorava então o chamado Sistema de Comunidade, que consistia, de forma resumida, em encarcerar todos os tipos de delinquentes, sem qualquer critério de separação, em espaços exíguos. Para Howard, este procedimento institucional impossibilitava a prisão de cumprir seu papel de ressocialização e, pelo contrário, facilitava e propiciava o contágio moral destes indivíduos, na medida em que, “juntava-se o reincidente com o recluso primário, o recluso saudável com o recluso doente, o condenado por crimes graves com o condenado por crimes leves e o criminoso já velho com o delinquente juvenil” (GONÇALVES, 2009. p 9). As propostas de reforma de Howard encontraram, ao mesmo tempo, opositores e apoiadores. Entre os opositores o argumento era de que as melhorias propostas por ele, que incluíam uma dieta melhorada, condições de higiene e vestuários mais dignas, dentre outras coisas, poderiam levar as classes baixas a preferirem as penitenciárias às suas próprias casas. Já seus apoiadores, acreditavam, como ele, que as penitenciárias não se tornariam lugares aprazíveis simplesmente por não mais corromperem física e moralmente os condenados, visto que seus ordenamentos internos, rigorosamente 
mantidos pelas equipes das prisões, seriam suficientes para infringir a justa medida de dor e sofrimento.

Segundo Coelho:

\begin{abstract}
Metade dos ordenamentos formulados por Howard aplicava-se aos administradores e aos guardas, visando eliminar o arbítrio, a crueldade e a exploração dos condenados. De fato, Howard estava preocupado com a legitimidade das prisões na percepção pública, mas sobretudo com a legitimidade das penitenciárias entre as "classes baixas". (COELHO, 2005. p 31)
\end{abstract}

Vê-se assim, que as propostas de reforma de Howard traziam consigo críticas significativas à forma como o sistema penitenciário vinha atuando, para ele, tal forma de agir não cumpria sua função, ao mesmo tempo em que acabava por desmoralizar os seus agentes.

Outro pensador, Jeremy Bentham (1748-1832), irá apresentar uma série de sugestões para otimizar a função desta instituição. Admirador das obras de David Hume e tributário da filosofia utilitarista, Bentham pauta nestes elementos uma parcela importante de suas reflexões e propostas de mudanças, entretanto, ele não as pensa como sendo úteis apenas para o sistema penitenciário, mas para a sociedade como um todo. Em sua obra "The Constitutional Code", publicada em 1830, apresenta, então, parte do que pensa acerca do sistema penitenciário, instituição que considera necessária para a sociedade. Ao falar sobre ela aponta para a necessidade de uma nova orientação em sua organização que deveria se pautar em três elementos: doçura; rigor e severidade.

Defende ainda que há a necessidade urgente da separação dos reclusos por sexos e tipo de crimes e que embora o regime disciplinar devesse ser rigoroso, aos encarcerados deveriam ser garantidos condições dignas de higiene, alimentação e vestuário. Entre as várias propostas de Bentham está, também, a de uma nova estruturação arquitetônica para os presídios, a esta criação dá o nome de Panopticon, que arquitetonicamente se apresenta como uma estrutura onde de um ponto central seria possível observar, de forma constante, o que aconteceria em todo seu entorno, ao mesmo tempo em que mantem o observador protegido dos olhares. O autor pressupunha que o espaço organizado desta forma, permitindo que os indivíduos estivessem em constante observação, acabaria por conter os impulsos individuais, propiciando a reforma moral desejada pela instituição. 
Revista NEP, Núcleo de Estudos Paranaenses, Curitiba, v.4, n.2, dez. 2018

Seguindo tais pressupostos alguns prédios, destinados ao encarceramento de condenados, acabaram sendo construídos, dentre eles a Eastern State Penitentiary em Filadélfia, a Pentonville Prison em Londres e a Millbank Prison, também em Londres, desenhada pelo próprio Jeremy Bentham. Sobre a efetividade de sua proposta, ou seja, de que a alteração no espaço alteraria profundamente o comportamento dos indivíduos, pouco ficou comprovado.

Cabe ressaltar ainda que Bentham apontava, assim como Howard, o comportamento dos operadores (guardas) destas instituições como um dos pontos que dificultavam o cumprimento de sua função. Para evitar tais problemas (como por exemplo a violência dos guardas contra os detentos) o autor afirmava que a total visibilidade propiciada pelo panóptico coibiria tais ações.

Como pôde ser notado, torna-se evidente que o longo período de tempo transcorrido entre o nascimento do sistema carcerário e a forma como ele hoje se encontra configurado foi marcado por transformações sociais, políticas, econômicas e culturais que alteraram sua forma de organização.

\section{Enquanto isto... no Brasil}

No que tange ao seu desenvolvimento no território nacional, o sistema penitenciário traça um percurso tal que, segundo Pedroso (2003), as políticas públicas voltadas a este setor se constituem num aparelho que atende as demandas de exclusão e repressão que vão além da prisão, promovendo o encarceramento dos considerados como potencialmente aptos ao cárcere (negros, vadios, estrangeiros, inimigos políticos, etc.). De maneira geral se observa que durante uma boa parte do período colonial eram seguidas, em terras brasileiras, as mesmas ordenações e códigos da Coroa Portuguesa. Foram seguidas, portanto, as ordenações manuelinas e as ordenações filipinas, somente em 1890 será criado Código Criminal do Império, momento em que os ideias de racionalidade - já discutidos anteriormente - começam a dar sinais de repercussão em território nacional. Segundo Moraes (2005) 
Revista NEP, Núcleo de Estudos Paranaenses, Curitiba, v.4, n.2, dez. 2018

É neste ultimo que passa a haver um impedimento legal aos castigos corporais e à pena de morte, e o encarceramento aparece com um formato mais "técnicocientífico". Passando a ser denominado de prisão celular, prisão com trabalho obrigatório e prisão disciplinar. (MORAES, 2005. p 172).

Moraes ressalta ainda que, aqui como também na Europa ou América do Norte, o fato de se travarem longas discussões acerca da organização das penitenciárias, de suas funções e funcionamento, ou mesmo das leis serem alteradas, não resultava, necessariamente, em mudanças efetivas nas práticas de tais instituições.

Enquanto se discutia sobre qual seria o sistema ideal a ser implantado para o funcionamento das penitenciárias no território nacional, se o Regime de Auburn, que pregava a separação dos presos durante a noite e o convívio dos mesmos durante o dia, com obrigação de trabalho e cumprimento da disciplina, se o Regime de Philadélfia, que propunha a reclusão celular continua e individual dos presos com a obrigação do trabalho, ou o Regime Irlandês ou Progressivo, que propunha um sistema intermediário que funcionava na transição entre o encarceramento e a liberdade, o que continua se assistindo, em território nacional, era o amontoamento de determinados estratos sociais em espaços exíguos. (PEDROSO, 2003)

Ainda assim as discussões proliferavam e se expandiam para várias áreas do conhecimento. A medicina, na época apoiada em ideais higienistas, dava suas contribuições e são várias as teses que têm o sistema penitenciário como tema. De modo geral se apontava que o crime, assim como as doenças, tinha um alto poder de contágio e que a mistura, em um mesmo ambiente, de indivíduos que cometeram crimes considerados leves com criminosos inveterados só poderia ter resultados funestos. $\mathrm{Na}$ tentativa de buscar uma solução para o problema se unem os discursos jurídicos, os da medicina e os religiosos. A ideia é a de que se tornasse possível, por meio do conhecimento formulado na interface destas áreas, formular ações que conseguissem não só curar e corrigir, mas também prevenir o crime. Com este intuito foram sendo construídas novas prisões em algumas cidades brasileiras, da mesma forma, novas designações e funções foram sendo incorporadas. As casas de correção, implementadas em algumas cidades, são exemplo disto. Segundo Moraes (2005) estas tinham como objetivo aprofundar a separação entre o mundo livre e a internação e para tanto seriam necessárias maiores preocupações acerca de sua arquitetura (influenciada pelo 
Revista NEP, Núcleo de Estudos Paranaenses, Curitiba, v.4, n.2, dez. 2018

panoptismo de Bentham) e localização. Não era mais recomendável que tivessem uma localização central, mas que ficassem afastadas das cidades (o que reforçaria o papel de isolamento dos indivíduos para reflexão de suas atitudes e comportamentos). Outra preocupação diz respeito ao corpo de funcionários que atuaria dentro destas instituições, era importante que os mesmos tivessem claro que sua função estava ligada a reeducação dos detentos, a eles cabia fazer com que o trabalho e a educação surtissem o efeito de cura e correção esperado da instituição, não sendo mais possível, portanto, que tais funcionários agissem com violência ou de forma arbitrária.

Moraes destaca ainda que, muito embora possam ser percebidas modificações no sistema penitenciário advindas destas discussões, elas não conseguem alterar o perfil de seus pré-destinados. Ou seja, se em outros países, a estas discussões se fazem acompanhar, de alguma maneira, a ampliação dos direitos dos cidadãos, o mesmo não ocorre no cenário nacional.

$* * *$

Se, de maneira geral, o sistema penitenciário foi pensado como possibilitador da regeneração dos indivíduos através de sua segregação temporária, ele não poderá, entretanto, afastá-los totalmente da sociedade de onde provêm, já que mesmo durante o período de reclusão forçada para os apenados há laços que os ligam ao universo extramuros. Na procura de atender sua função (e aqui está se pensando no discurso oficial destas instituições), o sistema penitenciário brasileiro, tem alicerçado suas políticas públicas, segundo Adorno (1991) em três frentes de atuação: o trabalho, a educação e a assistência jurídica e social.

Nota-se, porém, que a prática encontrada dentro destas instituições está longe do idealizado. Estudos efetuados no sistema penitenciário brasileiro ${ }^{3}$ apontam que tanto a formação profissional via educação, quanto o trabalho atendem a uma pequena parcela da população encarcerada e, ainda assim, de forma ineficaz, no que concerne a assistência jurídica e social não há grande diferença, nem mesmo existem profissionais suficientes ligados ao sistema para atender as suas demandas.

É neste sentido que se encaminham várias das críticas ao sistema, pois este tem como seu discurso legitimador uma função que não consegue atender, ou como diz 
Coelho (1987:13) "como pode pretender a prisão ressocializar o criminoso quando ela o isola do convívio com a sociedade e o incapacita, por esta forma, para as práticas da sociabilidade?".

É possível afirmar ainda que, internamente, estas instituições desenvolvem diversos mecanismos para sua sobrevivência (tanto da instituição em si, como de seus internos) mecanismos estes que passam longe do formalmente reconhecido. Várias normas, regras, procedimentos, comportamentos, etc., pertencentes ao universo do sistema penitenciário não se encontram escritos nos documentos oficiais que organizam o interior destas instituições, entretanto são eles que, muitas vezes, as mantêm funcionando ${ }^{4}$. Estes códigos estabelecem padrões de sociabilidade e propiciam a construção de identidades que tornam a convivência dentro deste universo mais confortável, tanto por parte dos internos, quanto da equipe dirigente. Em certo sentido, isto torna possível um mapeamento da instituição e a localização dos indivíduos dentro da mesma. E até mesmo o frágil equilíbrio que mantém estas instituições funcionando está relacionado à possibilidade de leitura destes códigos.

Um dos elementos, dentre os vários utilizado na manutenção do equilíbrio interno deste sistema e reconhecido como essencial para o funcionamento do mesmo são as visitas.

Utilizadas como termômetro, elas podem servir à instituição como indicador das possibilidades de recuperação dos internos visto demonstrar a manutenção de laços com o mundo externo.

As visitas, principalmente dos familiares, evidenciam que há do lado de fora dos muros alguém que se preocupe com a recuperação do interno. "O fato do preso ter família, e desta ser capaz de interceder por sua sorte junto à autoridade, influi positivamente no processo de recuperação" (RAMALHO, 1979. p 135). Entretanto, sabese também que são elas que mantêm o que Coelho (1987) denomina de "economia delinquente". A entrada de $b_{e n s^{5}}$ que serão negociados posteriormente dentro das prisões

\footnotetext{
${ }^{4}$ Em seus trabalhos, tanto Ramalho (1979), quanto Coelho (1987) falam a respeito destas normas de sociabilidade internas ao sistema, bem como de que maneira as mesmas informam acerca de sua constituição interna.

${ }^{5}$ Coelho (1987) afirma que são trazidas pelas visitas, tanto objetos que supririam as necessidades básicas dos detentos, necessidades estas que não são atendidas pela instituição (roupas, artigos de higiene, doces, cigarros, comida, etc.) como também dinheiro, tóxico e armas
} 
só é possível, segundo ele, pois há uma rede de cumplicidade entre os presos e os setores administrativos.

Por outro lado, para os detentos as visitas significam que estes não estão abandonados a sua própria sorte, não se constituindo no que é chamado internamente de caído. "O caído é o interno sem família ou desassistido por ela, que não tem "visita"; abandonado e "esquecido" dentro das prisões (...)" (COELHO, 1987. p57).

Segundo Evangelista (1983:50), "no período de detenção, fica evidente a importância que tem para o preso o apoio de familiares e de amigos, principalmente dos primeiros". Contraditoriamente, ainda segundo esta autora, é através das visitas que o preso sentirá com maior intensidade o peso de sua condenação, já que seus familiares gozam da possibilidade de entrar e sair e ele estará impedido de fazer o mesmo. "É ainda através das visitas que os presos entram em contato com as situações enfrentadas por seus familiares do lado externo dos muros, situações sobre as quais, muitas vezes, ele não tem possibilidade de atuação6". (EVANGELISTA, 1983; SILVA, 2006).

De qualquer forma, como já se apontou acima, a presença da família é pensada como fundamental para a manutenção do funcionamento desta instituição, seja por poder ser utilizada como elemento diferenciador no qual se aponte o caminho da regeneração, ou por ser elemento de garantia de "sobrevivência" dentro do sistema, suas visitas são aguardadas com ansiedade. A elas (famílias), como já vimos, recai uma dupla responsabilidade: a da conservação dos laços com os internos e a de manter-se do lado de fora dos muros da instituição aonde se encontram um ou mais de seus membros reclusos. Entretanto, o fato de se reconhecer a necessidade das visitas dos familiares e amigos não torna as mesmas algo agradável ao corpo técnico, ou a equipe dirigente. Quando muito elas - as visitas - são pensadas como inevitáveis, ou, como ouvi em determinado momento de um agente: "são os ossos do ofício".

\section{Diversas falas de uma instituição.}

Após ter exposto, ainda que de forma rápida, a construção social da pena de privação de liberdade e do sistema penitenciário, parece ficar mais fácil compreender o tom de certas

\footnotetext{
${ }^{6}$ Silva (2006), em um estudo sobre a educação que ocorre atrás das grades afirma que se por um lado, os presos pensam em retornar ao convívio familiar e através da educação recebida na instituição contribuir para a formação de seus membros, a equipe dirigente, muitas vezes, vê na preocupação de seus internos com o que ocorre aos seus familiares fora dos muros da prisão um dos elementos que contribuem para um rendimento baixo escolar.
} 
falas advindas da equipe dirigente (corpo técnico). Aqui apresento e discuto o resultado tanto das entrevistas que me foram concedidas, quanto das conversas informais que tive durante todo o período em que frequentei as filas de visitas.

Vale ressaltar em meu primeiro dia de campo fui abordada por alguns agentes penitenciários que estavam de plantão naquele final de semana. Interessados em saber o que eu estava pesquisando, foram eles que me passaram a informação, que eu desconhecia, de que a rebelião de 2010 na PCE tivera como resultado a organização de uma associação que reunia familiares de internos do complexo penal de Piraquara. Segundo eles, tais familiares, além de pedirem esclarecimentos acerca do que havia acontecido na citada rebelião, aproveitavam também para fazerem exigências e denúncias sobre o sistema penitenciário no estado.

Frente a tal notícia dei início a um processo de busca por maiores informações sobre tal associação. Acerca dela e suas atividades há bem pouco material disponível, o que pude levantar é que a mesma acabou tendo um número reduzido de reuniões. Apoiadas por uma ong (Iddhea - Instituto de defesa dos direitos humanos) e pelo Crees (Conselho Regional de Serviço Social) cerca de dez mulheres oficializaram, em janeiro de 2010, a criação da associação que se propunha a lutar por melhores condições de tratamento para os detentos, não só da PCE (unidade em que houvera a rebelião) mas de todo o sistema penitenciário paranaense. O fato é que tal associação acabou tendo uma vida curta, embora ainda exista oficialmente - visto ter sido oficializada - não se tem mais notícias de sua atuação. Segundo um assistente social com quem conversei, a associação acabou tendo um escopo de movimentação muito pequeno. Para ele, como a grande maioria das mulheres que a fundaram eram parentes de detentos da PCE a pauta de discussão e exigências tornou-se muito limitada e, como a maior parte do que elas exigiam acabou sendo, de uma forma ou outra, atendido, o movimento foi perdendo força. Ainda segundo este assistente social, outro elemento que esvaziou o movimento foi a tentativa, por parte de uma das associadas, de utilizar a recém-organizada associação como alavanca eleitoral; teriam sido estes os fatores que fizeram com que o movimento acabasse de forma tão rápida. 
Tive, entretanto, uma impressão diferente quando conversei com uma das mães que fizera parte da organização da associação. Selma ${ }^{7}$ participou das primeiras reuniões da associação e, após falar publicamente sobre as condições de vida dos detentos e o tratamento dispensado aos familiares dos mesmos no sistema penitenciário foi abordada, na fila de visita, por um agente penitenciário que pedia explicações sobre o tom de sua fala. Segundo ela, outras mães que também participaram de tal reunião foram, como ela, abordadas, isto serviu para que ela repensasse sua participação e se retirasse da associação. Embora não possa afirmar com certeza ser este o motivo do desmonte do movimento, acredito que exista alguma possibilidade de que a pressão feita por elementos da(s) equipe(s) dirigente(s) possa ter influenciado no rápido desaparecimento de tal associação.

Sobre este tema (a criação da associação e as reclamações dos familiares) ouvi, certa vez, a opinião de um agente penitenciário. Semanalmente, após a entrada das visitas na unidade (que eu não podia acompanhar), passava rapidamente na guarita e conversava com os agentes que estavam de plantão. Procedi com eles da mesma forma que com minhas informantes - familiares de presos e presas - frente à resistência da concessão de entrevista formal, utilizava estes rápidos bate papos como fonte de informação.

Segundo $\operatorname{Ivan}^{8}$ (agente penitenciário), os familiares reclamavam muito e de tudo. "é bem difícil de lidar com eles às vezes, se você cumprimenta e trata bem, já quer tirar intimidade, se fica de cara fechada é grosso... não é fácil!"’ Para ele, a situação em que se encontravam os detentos era resultado de seus próprios atos, sendo assim eles tinham o que mereciam ter. Via, entretanto, com um pouco mais de simpatia, a situação dos familiares. "algumas destas mulheres já estão nesta vida há anos... nos finais de semana que vem só as mães e as crianças então, a situação é mais difícil ainda, se tá chovendo, ficam elas e as crianças tomando chuva, esperando o portão da unidade abrir, às vezes dá pena.'

Diz ainda não aprovar a visita das crianças, segundo ele: isto não é ambiente pra criança. Aqui tem muita coisa que não presta. Frente a tal posicionamento, não pude deixar de perguntar o que ele pensava sobre as crianças que ficavam na creche da

\footnotetext{
${ }^{7}$ Nome fictício atribuído a uma das mães entrevistadas durante a pesquisa de doutorado.

${ }^{8}$ Todos os nomes apresentados nesse texto são fictícios.
} 
Revista NEP, Núcleo de Estudos Paranaenses, Curitiba, v.4, n.2, dez. 2018

feminina9 com suas mães. Sua resposta foi imediata: "não precisa nem dizer o futuro que elas vão ter né”? Na sequência, termina sua reflexão se posicionando sobre as reclamações e reivindicações dos familiares de presos e presas. "você tocou num assunto importante... não vejo ninguém reclamar sobre isto (ele se refere as crianças na creche), nem a tal associação das mães falou deste assunto, eu acho um absurdo! Tem gente ai dentro (se referindo a direção da unidade) que diz que é direito deles, que as mães têm o direito de ficar com seus filhos, de dar o peito pro seus filhos. Direito? Direito de quê? De ficar com os filhos presos junto com elas? Isto tá certo? Eu acho que não... se fosse filho meu, tomava mamadeira, leite de vaca, mas não ficava na cadeia! Que é que a criança fez pra ficar preso? Vai ficar marcado, traumatizado pro resto da vida... e tudo isto pra que? Pra poder mamar no peito?”

Muito embora este assunto não tenha mais aparecido em minhas conversas com os agentes (o direito das mães em ficar com seus filhos na unidade), algumas vezes ouvi deles reclamações sobre o comportamento dos familiares dos presos e presas. Segundo eles, algumas mães e esposas se comportavam como se eles fossem "empregados delas". De um deles ouvi a seguinte afirmação: "às vezes não tem jeito, você tem que falar grosso que só assim elas entendem... aqui tudo tem ordem, tá tudo organizado pra o negócio funcionar direito, elas vem aqui e acha que a gente pode dar um jeito... se tem todas as informações, do que pode trazer, do que não pode, porque que não cumpre? Dai quer entra! Quer entra, entra, mas o que trouxe errado, o que não pode entrar (se referindo ao lanche trazido pelos familiares), vai fica do lado de fora.". Outro agente que estava também na guarita também, dá sua opinião acerca das relações que acontecem no sistema. “acho que muita coisa acontece por que aqui todo mundo tem direito, menos a gente. Se alguma coisa acontece com a mãe de um preso, tem alguém pra garantir os direitos delas. Se acontece alguma coisa com preso, vem o pessoal dos direitos humanos reclamar, mas

\footnotetext{
${ }^{9}$ A creche da Penitenciária Feminina do Paraná (chamada de Cantinho Feliz) foi criada na segunda metade dos anos 70 pela doutora Eny Carbonar, que esteve na direção desta unidade 1975 a 1983. Embora seu projeto original afirme que as crianças poderiam ficar com suas mães até os 6 anos de idade, hoje o tempo de permanência máximo - pelo menos teoricamente - é de 4 anos. Digo teoricamente já que quando visitei a creche - acompanhando uma ação da Igreja Batista do Bacacheri- as agentes que lá estavam me informaram que é extremamente raro as crianças permanecerem lá após os 3 anos. Na fala de uma destas agentes, este é o tempo limite já que: "parece que a partir dai ela já começa entender o que está acontecendo, que ela também tá presa”. Para saber mais sobre o tema, conferir a dissertação de Quintino, 2006. UFPR
} 
Revista NEP, Núcleo de Estudos Paranaenses, Curitiba, v.4, n.2, dez. 2018

e a gente? Pra gente sobra mesmo é a bronca!" Completa seu desabafo dizendo: "você vai ouvir muito isto ai dentro, se é que já não ouviu... que quem estraga o sistema somos nós... que nós isto, nós aquilo... que a gente estraga todo o trabalho que eles fazem lá dentro! Mas de verdade, quem aguenta o rojão somos nós! Na hora do" vamo vê", quem é que tá lá no fundo da cadeia? Tem algum assistente social? Tem psicóloga lá? Não... é a gente que tá lá!’”.

Moraes (2005) já apresentou em seu trabalho sobre a identidade dos agentes penitenciários, posicionamentos próximos a este. Enquanto conversava com os agentes sobre o trabalho que desenvolviam dentro das unidades do sistema, uma das queixas mais frequentes era a de que, para o restante do corpo técnico ou equipe dirigente, são os agentes penitenciários os impossibilitadores, em grande parte, de que a instituição cumpra seu papel de ressocializador. Os agentes falam ainda que durante o período de formação, anterior a entrada nas unidades, eles foram instruídos acerca do importante papel que exerceriam como agentes socializadores; frisam, contudo, que a realidade encontrada no interior do sistema não possibilita em nada que eles cumpram tal função, ao contrário, a prioridade é e será sempre a de manter a ordem, a disciplina, enfim, a segurança das unidades. É aqui que se encontra um ponto fundamental na contradição de discursos e práticas deste mesmo corpo técnico- estamos incluindo os agentes penitenciários neste corpo - enquanto os agentes, segundo eles mesmos, precisam aprender como lidar com os presos, precisam aprender a "escutar a cadeia", " sentir seu estado", , para daí saber as atitudes que devem ser tomadas, cobra-se deles, ainda, que sirvam como elemento de ressocialização.

Uma coisa que foi muito debatida nesse curso foi a ressocialização, o papel do agente penitenciário como reeducador e o elemento de ligação entre o (...) maior responsável pelo reingresso do preso no convívio social. Só que quando você chega na cadeia você descobre que o único princípio de ressocialização que

\footnotetext{
${ }^{10}$ Segundo os agentes penitenciários, as cadeias têm uma espécie de estado ótimo. A percepção deste estado, entretanto, não é coisa fácil de desenvolver, ela só se dava por meio da utilização de diversas variáveis e para reconhecer tal estado se faz necessária à utilização de todos os sentidos. Moraes apresenta sobre isto uma ótima referência oferecida por um de seus informantes. Segundo tal informante: “(...) se tem uma rotina, saiu dessa rotina abre o olho que tem alguma coisa errada. Então como eu te disse, se a cadeia tá ruim, buxixo, sabe, conversa, boato, boataria sobre doente, sobre fuga, sobre isso sobre aquilo, é até mais fácil trabalhar porque você trabalha preparado. Agora se a cadeia tá quieta, você põe o pé atrás que alguma coisa tá errada. É a mesma história, você tá num pátio, o pátio ele já sabe como é que tá. Se os presos estão andando prá lá e prá cá, tem três, quatro presos sentados numa rodinha ali jogando baralho, jogando qualquer coisa lá ou conversando, o pessoal lá do (...) jogando capoeira e tal, tá normal. Agora se tem três ou quatro bandidos andando no meio do pátio e o resto tiver tudo encostado na parede, você pode correr atrás que tem faca na parada, alguém vai pular, entendeu? Então é uma manha que você tem no serviço, você já sabe como é que tá. (apud MORAES, 2005. p 225)
} 
existe é a disciplina, é cobrar e exigir disciplina. Então daí já foi o primeiro (longo silêncio) a primeira desilusão, vamos dizer assim. Preparam nós pra uma coisa que não existia, quer dizer uma utopia. Falava em ressocializar e o sistema não favorece em nada a ressocialização.

(...) quando eu cheguei na penitenciária eu descobri que eu tinha que ser um segurança. Ou seja, nós temos que tá lá pra manter a disciplina e manter a ordem na cadeia, manter as coisas funcionando. Então. se consomo muito tempo nisso e sobra pouco tempo pra você ressocializar, mesmo porque o sistema não favorece, não tem como ressocializar. (apud MORAES, 2005. p 240)

Moraes, na sequência, mostra como as relações entre os diversos segmentos do corpo técnico são tensas e contraditórias.

Nós tamos quebrando o gelo devagar. Quando eu entrei no sistema era uma coisa horrível, nós erámos discriminados, pô, descaradamente. Elas preteriam nós aos presos. O preso coitadinho tava privado de liberdade, tava numa situação é...é... desprivilegiada vamos dizer assim, não tinha liberdade para ir e vir e tinha que obedecer ordem e coisa tal. E nós erámos os achacadores, acossadores dele, cobrando, sabe, dando ordem, então a conotação que ela tinha de nós, era que nós erámos um bandido piorado...Nem bandido não era, porque o bandido tinha o respeito delas e nós não tínhamos, então (...) houve muito pega. (apud MORAES, 2005. p 247)

Tal informante relata, ainda que as coisas estavam mudando e que enfim, os agentes e o restante do corpo técnico estavam buscando criar mecanismos para tornar a prática e o discurso da instituição mais homogêneo. Este mesmo informante diz perceber que o restante dos técnicos que atuam na instituição tem pouco conhecimento do trabalho deles e do que seja o fundo da cadeia e reforça a ideia de que qualquer problema no trabalho deles - restante do corpo técnico - irá reverberar no trabalho dos agentes, pois, como eu já havia ouvido também de um agente, quem aguentava a bronca no final, eram eles. Embora este agente aponte para mudanças nas relações entre os vários segmentos da equipe dirigente ${ }^{11}$, isto nem sempre é perceptível nas falas e práticas destas instituições. Em vários momentos ouvi, por parte do restante do corpo técnico, relatos que ainda se aproximavam muito do apresentado pelo informante de Moraes, citado acima. Em várias situações e lugares ouvi posicionamentos que remetem aos agentes penitenciários a responsabilidade pelo não funcionamento da instituição.

\section{O trabalho de Penélope ${ }^{12}$}

(...todo o trabalho que fizemos durante o dia, eles desfazem de noite! Assistente social)

\footnotetext{
${ }^{11}$ Neste momento estou usando os termos corpo técnico e equipe dirigente como sinônimo.

${ }^{12} \mathrm{O}$ título está ligado a personagem de Penélope, esposa de Ulisses - Odisseia.
} 
Em outubro de 2010 participei em Brasília de um seminário organizado pelo Ministério da Justiça, ele tinha como objetivo discutir a educação oferecida no sistema penitenciário $^{13}$ para os homens e mulheres que cumprem pena de privação de liberdade. Para refletir sobre o assunto foram convidados e convocados uma série de instituições e indivíduos envolvidos, de alguma maneira, com o tema e/ou com o sistema penitenciário. Fui como pesquisadora do CESPDH (embora não estudasse especificamente o tema da educação no sistema penitenciário ${ }^{14}$, conhecia bastante bem a realidade do processo educacional, pelo menos em uma das unidades do complexo penal de Piraquara, qual seja a PCE) e pude acompanhar uma série de atividades, discussões e trocas de experiências entre várias instituições penais. De maneira geral, todo o Brasil estava representado neste evento, bem como alguns países da América Latina. Conversei com psicólogos, assistentes sociais, pedagogas, diretores de unidades, pesquisadores de universidades, representantes de ongs e até mesmo com professores que atuavam no sistema penitenciário, mas, surpreendentemente, não havia entre nós nenhum representante dos agentes penitenciários. A discussão toda esteve em torno das possibilidades de sucesso deste tipo de empreendimento nos sistema carcerário e das implicações dos envolvidos no mesmo para que isto acontecesse, por isso mesmo, a organização do evento reforçava o tempo todo que garantira a participação de todos os interessados pelo tema (como o evento era organizado pelo Ministério da Justiça, os servidores do sistema tiveram liberação do trabalho e todas as despesas pagas). Em alguns grupos de trabalho dos quais participei (os grupos de trabalho tentavam misturar representantes de todos os setores participantes do evento) cheguei a comentar a ausência dos agentes penitenciários e em vários momentos ouvi a mesma resposta: "eles não têm nada a acrescentar". Conversando mais demoradamente com uma assistente social de Minas Gerais pude entender mais claramente o que motivava tal fala. Segundo ela, os agentes penitenciários trabalhavam contra o sistema. Por não terem uma formação ideal - grande parte dos agentes que atuavam na unidade em que ela trabalhava à época, não teria o ensino médio

\footnotetext{
13 Seminário Nacional de Consolidação das Diretrizes para a Educação no Sistema Penitenciário (realizado em Brasília, em outubro de 2010)

14 Acompanhei de forma bastante próxima a produção de uma dissertação (Silva, 2006) que tinha como objeto a educação no sistema penitenciário, especificamente a possibilidade de se desenvolver uma educação tecnológica neste contexto.
} 
Revista NEP, Núcleo de Estudos Paranaenses, Curitiba, v.4, n.2, dez. 2018

completo - eles não conseguiam perceber a importância de seu trabalho de ressocializador, eram ainda carcereiros e como tal atuavam. Esta pareceu ser, ao menos nos grupos em que participei, uma opinião bastante recorrente.

No contraponto, ouvi com a mesma frequência sobre as possibilidades de sucesso da função ressocializadora do sistema penitenciário. Ouvi isto de psicólogas, diretores de unidades, assistentes sociais, entre outros. As críticas vinham, em geral, dos pesquisadores.

Esta postura, que aqui vou chamar de romântica, vinda dos operadores do sistema e, principalmente das/os assistentes sociais, me deixou bastante surpresa. Entre os vários trabalhos desenvolvidos pelos pesquisadores do CESPDH estava o de Julia Shella (2007), nele a pesquisadora analisa as representações sociais acerca das possibilidades de sucesso da função de ressocialização do sistema penitenciário, escolhendo como interlocutor privilegiado as assistentes sociais por entendê-las como centrais nesta função. Sua conclusão é a de que estas profissionais não acreditam nesta possibilidade.

\begin{abstract}
A conclusão a que chegamos é que essas profissionais não acreditam na reabilitação e nem se consideram centrais nesse processo. E a falta de crença na reabilitação não se deve à ineficácia da prisão em si ou à ineficácia do serviço social, mas sim à falta de apoio estatal ao sistema prisional e aos recursos humanos que nele atuam. (SHELLA, 2007. p ix)
\end{abstract}

Somente mais tarde, refletindo sobre o tema me dei conta de que, de certa maneira, a fala da assistente social com quem eu conversei no evento em Brasília, bem como as representações apresentadas por Schella têm o mesmo fundamento. No geral compartilham a percepção de que o sistema poderia funcionar caso todos os envolvidos com ele se implicassem realmente no processo. A fórmula do sucesso parece envolver uma série de "sês": Se o sistema penitenciário tivesse mais verbas, se o sistema penitenciário tivesse mais pessoas, se as pessoas que atuam no sistema fossem mais qualificadas, se a sociedade não visse o interno e o egresso com tanto preconceito, se o preso colaborasse,... uma infinidade de variáveis que quando somadas tinham como resultado o insucesso que tornava a todos insatisfeitos, porém, disposto a continuar tentando e, principalmente, reforçando a legitimidade da instituição da qual participam, afinal o problema não era exatamente ela, mas sua configuração. Impossível não lembrar 
aqui dos reformadores e da constatação foucaultiana que aponta para o fato de que o sistema penitenciário já nasce marcado pela vontade/necessidade de reforma.

A assistente social mineira, as assistentes que Shella entrevistou, bem como os/as assistentes sociais com quem eu conversei em minha pesquisa têm em comum a crença de que o sistema poderia funcionar caso o "ses" não existisse e, entre estes "ses" figura o trabalho desenvolvido pelos agentes penitenciários.

Em uma das minhas conversas com os assistentes sociais de Piraquara ouvi a frase que transformei em epígrafe desta seção: "às vezes tenho a sensação de que todo o trabalho que fizemos durante o dia, eles desfazem durante a noite". Vem dai o título. Para ele e sua colega, também assistente social, de certa forma, os agentes prestam um desserviço ao sistema. Todo o trabalho feito pelos assistentes sociais, no sentido de reintegrar (ou mesmo manter os vínculos entre) os presos e a sociedade é desfeito pelos agentes quando os internos são enviados novamente para as celas. Relatos de atitudes de má vontade dos agentes com relação às necessidades do serviço social, das psicólogas ou mesmo do jurídico das unidades são bastante recorrentes. Quando qualquer pessoa do corpo técnico solicita a presença de um interno para a prestação de um serviço, uma entrevista, ou qualquer atendimento, precisa contar com a boa vontade dos agentes em trazê-los até onde foi solicitado, o que nem sempre acontece. Para estes assistentes sociais, os agentes usam sempre a desculpa da segurança para não atenderem de imediato as solicitações. "eles tentam marcar território, sabe como é? No fundo eles querem é mostrar pra gente que sem eles aqui a coisa não funciona. (silêncio).(...) Você passa, às vezes, horas conversando com um interno, explicando as coisas, encaminhando o sujeito pra ele passar o menor tempo possível por aqui... e eles, já no caminho de volta pra cela, vão dando ideias pros internos, falando pra eles não levarem em conta nada do que a gente fala, que é tudo papo furado...que o negócio aqui é seguir as regras e se dar bem(...) É assim que acontece, nem parece que a gente trabalha junto, parece que são dois times..."

Com relação ao tratamento dado pelos agentes aos familiares dos internos e internas as reclamações dos assistentes sociais são recorrentes. Segundo eles, muitas vezes os responsáveis pela demora na confecção das carteirinhas (credenciais de visita) são os agentes que passam informações erradas aos familiares. "não que eles não saibam do que precisa, eles sabem sim, tem com eles - na guarita de entrada - uma folha como 
Revista NEP, Núcleo de Estudos Paranaenses, Curitiba, v.4, n.2, dez. 2018

esta que eu te entreguei (a assistente fala do panfleto de informações sobre os documentos necessários para fazer a carteirinha), mas eles passam tudo pela metade, dai o familiar vem e não tá com tudo o que precisa, que é que eu vou fazer? Tenho que mandar ele embora e trazer o resto! De certa forma, a assistente social reforça aqui algo que já me havia sido relatado anteriormente, tanto por familiares dos internos e internas, quanto por motoristas de táxi que fazem o percurso entre o ponto de ônibus e o complexo penal, isto é, fazer uma carteirinha requer um esforço significativo por parte dos familiares. São idas e vindas sequenciais para dar conta de organizar e trazer todos os certificados e documentos exigidos pelas instituições, os familiares ainda têm que enfrentar um fluxo de informações desencontradas e contraditórias, que segundo os assistentes sociais com quem conversei, tem relação direta com a queda de braço em que vive o corpo técnico em geral e os agentes penitenciários. Na perspectiva de um assistente social específico, tal postura está ligada a tal "marcação de território". “(...)tem muito disto aqui, eles passam a informação pela metade e daí quando vem o familiar e não trouxe tudo que necessitava você pergunta pra ele quem foi que passou a informação e a pessoa não sabe dizer. "Ah! Eu falei com um homem que tava na portaria." Mas que homem? Quem? Qual o nome? O familiar não sabe ou não quer falar.... por isso é que foi criada a central de credenciamento, pra tentar dar uma uniformizada, uma organizada mesmo neste negócio.... agora tá tudo com a gente, não tem mais essa de eu falei com uma pessoa no telefone ou na portaria, quem tá aqui sabe quem trabalha aqui e agora é só aqui que ele tem as informações." Entretanto, segundo ele, ainda há muito a ser feito, embora as unidades não possam e não tenham criado problemas com relação a centralização da confecção das credenciais, persistem arestas que precisam ser aparadas.

A central de credenciamento foi criada quando esta pesquisa já estava em andamento e já havíamos ouvido os/as assistentes sociais das unidades pesquisadas. Pela necessidade de outras informações, ao buscar novamente os assistentes sociais das unidades fui informada de que a confecção das carteirinhas agora era feito pela central de credenciamento e que, portanto, deveria me reportar e ela. A criação desta central está ligada a tentativa de padronização dos procedimentos para a concessão de credenciais para visitas. Segundo o assistente social com quem conversei, embora o procedimento fosse comum a todas as unidades, havia a possibilidade de interpretações diversas em cada uma das unidades, ao centralizar tal atividade estas disparidades estavam 
Revista NEP, Núcleo de Estudos Paranaenses, Curitiba, v.4, n.2, dez. 2018

solucionadas. Resta, entretanto, a possibilidade de mesmo com a credencial fornecida, existirem entraves relativos à segurança. Novamente será dos responsáveis pela segurança a palavra final acerca da entrada ou não de visitas nas unidades. Embora funcionando, à época da entrevista, há apenas três meses, os assistentes sociais que nela atuavam já eram capazes de apontar mudanças sensíveis com relação à organização das visitas nas unidades do complexo penal de Piraquara e esperavam, com isto, dar início a postura de transformação no comportamento organizacional de todo o sistema. A ideia não era somente a afinar a organização no que se referiam as credenciais, mas também, na medida do possível, imprimir ou outro tom ao atendimento dos familiares dos internos das unidades do complexo penal.

Os profissionais com que conversei na central de credenciamento tinham, com relação aos familiares dos internos, uma postura que chamarei de paternalista moralista. Ao mesmo tempo em que apontavam para uma suposta desestruturação familiar - algo que poderia ter levado os indivíduos ao crime -, falavam sobre a necessidade de respeito aos familiares. Quando, ao conversar com ela, apresentei como objeto da minha pesquisa, qual seja, as famílias de presos/presas, ela me respondeu afirmando: “acho que já começa errado daí, ninguém é preso, ele está preso!"

Partindo desta ideia, esta assistente social afirma que tanto os presos/presas, quanto seus familiares têm, quando entram em contato com a instituição, uma postura de “totalmente subalternizada, vencida e envergonhada”. Postura essa reforçada pelo sistema, segundo ela: "é inacreditável você ter que lembrar aos seus colegas de trabalho que estes indivíduos também são sujeitos de direito." Para ela, a primeira providencia a ser tomada, sempre que um familiar entra em contato com eles pela primeira vez é a quebra desta postura subalterna. "eles (os familiares) não estão pedindo nenhum favor, eles têm o direito de visitar seus familiares. Ao contrário, somos nós que precisamos deles aqui, os internos precisam manter seus laços familiares, eles vão voltar para a sociedade em algum momento e a família é essencial para isto."

Novamente atua no imaginário social destas pessoas, ainda segundo a assistente social, a ideia de que a família de preso é criminosa também. Usa uma expressão bastante parecida com a que ouvi do agente penitenciário na minha primeira ida a campo: "para eles - agentes - preso não tem família, preso tem quadrilha." Bastante curiosa acerca dos resultados da pesquisa que eu desenvolvia, essa assistente me relata que ela mesma já 
tivera, muitas vezes, a vontade de frequentar as filas de visitas e checar de perto algumas reclamações que dizia ouvir.

Para ela o trabalho desenvolvido pelo sistema penitenciário é fundamental para a sociedade, lamenta apenas que muitos de seus companheiros de trabalho não consigam perceber sua relevância e tratem/pensem o sistema como um depósito de marginais. "não há sentido no nosso trabalho se a gente não conseguir fazer com que estas pessoas voltem bem para a sociedade, é prá isto que nós estamos aqui, é pra isto que pagam o meu salário e o salário deles também."

Como já apontei acima, ela corrobora a ideia de que os laços familiares, bem como a visita dos mesmos são fundamentais para a reinserção social dos internos, contudo parece também ter clareza de que a administração destes laços não é tarefa fácil. Ela e seu colega vão me apontando alguns exemplos dos motivos que os fazem pensar assim. O primeiro ponto apontado por ambos seria, hoje, a organização das facções dentro do sistema e a sua expansão para fora dos muros das unidades. Segundo eles, os familiares acabam também se tornando reféns destas facções, na medida em que seu familiar detido entra para o partido, querendo ou não, os familiares ficam submetidos às regras e normas organizacionais do mesmo. Segundo ela: "quando um familiar é pego trazendo dentro de seu corpo um objeto... pode ter certeza de que ele foi aterrorizado pra se submeter" Aproveito a deixa e pergunto se há - ou houve - um número muito grande de familiares sendo pegos em tais atos e sua resposta é intrigante : "não tenho como te responder isto... e não é por que esteja querendo esconder nada não... que eu não faço este tipo, é por que a gente não tem, aqui dentro, estatística de nada... prá gente conseguir um número aqui dentro, você não imagina o trabalho que temos... então a gente faz estimativas... pra tudo... é assim que a gente trabalha."

Continua fazendo uma crítica ao que ela identifica como certa informalidade na organização administrativa, para ela, administrar sem se ter certeza dos números é algo como fazer adivinhações. Usa como exemplo as taxas de reincidência: "já ouvi falar que as taxas de reincidência beiram os $90 \%$, outras pessoas me disseram que estava em torno dos $70 \%$... mas na verdade, quem é que sabe? Como é que isto é contabilizado? Você conhece algum trabalho sério que aponte estes dados de maneira confiável? Eu não conheço! Aqui todos os números são assim.” Na sequência, tenta apresentar alguns motivos para que tal fenômeno aconteça. "eu entendo que todo mundo está 
Revista NEP, Núcleo de Estudos Paranaenses, Curitiba, v.4, n.2, dez. 2018

sobrecarregado aqui dentro, e que existem muitas tarefas mais importantes que ficar preenchendo planilhas... mas, por outro lado, se a gente tivesse uma clareza maior do que realmente a gente tá fazendo, quem são, de onde vem, que resultados a gente tem com as pessoas que passam por aqui (...) a gente talvez conseguisse atacar os problemas certos!"

Ao mesmo tempo, eles parecem querer reforçar que o fato de que a não existência de números exatos não significa que eles não conheçam o universo com que trabalham. "não que a gente não saiba, por experiência, pela vida aqui dentro, todas estas informações... a gente sabe, a gente conhece bem tudo isto (...) mas precisa sim alguma maneira de juntar todas estas informações de todas as unidades pra ter maior clareza."

Acredito que de alguma maneira, os dois assistentes estivessem buscando formas de apresentar suas críticas sem, necessariamente, ter que aprofundá-las a ponto de repensar todo o sistema e, consequentemente, seus papéis dentro dele. Assim, recorrem inconscientemente(?) à estratégia de apontar a falta de estatísticas, de números confiáveis, como um elemento crucial nos problemas encontrados na instituição na qual trabalham. De certa forma, parecem não perceber que para além da produção dos números, a interpretação dos mesmos teria um papel fundamental a cumprir e acabam resvalando na ideia de que o número, por si só, porta uma verdade e um poder, sendo assim, não avançam suas reflexões no sentido de perceber que dá produção dos números à confecção de uma política pública - bem como que tipo de política será produzida - com os mesmos, há um outro e longo caminho a ser percorrido.

Retomo a conversa reintroduzindo o tema da relação entre o corpo técnico e os familiares. A assistente social, então, apresenta uma reflexão sobre o que, para ela, é o ponto tenso na relação entre os agentes e os familiares dos internos/internas. Segundo ela, embora os agentes tenham consciência da necessidade da presença dos familiares nas unidades e reconheçam que sem ela é impossível segurar a cadeia, isto não significa que eles gostem disto. Como pensam os internos/internas como vagabundos, não se conformam com o fato de que eles tenham alguém por eles e segundo ela, só há uma forma de equilibrar esta equação, isto é, colocar a família dos presos e presos no mesmo patamar em que colocam os internos, assim: "família de vagabundo só pode ser vagabunda também”. "Então a questão é a seguinte, se a família quer continuar 
convivendo com o preso, isto não vai ser doce... vai ser sofrido... A assistente fala também sobre a revista íntima, diz achá-la bastante violenta e afirma já ter ouvido relatos bastante fortes sobre a mesma, relata ainda que durante algum tempo foi totalmente contrária a sua realização, hoje, porém, está rendida a sua necessidade. "sei que é humilhante, mas nós não temos como evitar, ainda mais hoje quando as facções dominam todos os ambientes... a tendência é tornar tudo ainda mais severo." Continua sua reflexão dizendo: "os familiares, como te disse, acabam sendo coagidos pelas facções a trazerem coisas pra dentro do sistema e na maioria das vezes, as mulheres ou mães não trazem coisas pros seus familiares, mas pra alguém da facção. Elas vêm coagidas, aterrorizadas, por que sabem da possibilidade de serem pegas, mas não tem como evitar. " Insisto no tema dizendo que uma parte das tais coisas que entram nas unidades não são trazidas apenas pelos familiares dos internos e que, em alguns casos, há a participação e a conivência de funcionários do sistema ao que ela responde de forma afirmativa. "claro que há... mas não acho isto tão ruim, por que veja, este funcionário é corrupto, foi comprado, é isto, abre-se uma sindicância e ele é punido e desligado. Já o familiar? Que é que ele pode fazer? Se ele foi coagido a trazer alguma coisa, vai recorrer a quem? Isto sim é muito mais violento que a revista íntima, por isso hoje eu já analiso ela de uma forma diferente, penso que de alguma maneira ela diminui as tentativas dos familiares de trazer coisas, por que eles sabem que vão ser pegos."

A partir disto ela fala sobre as famílias dos internos e internas e sobre o que pensa acerca das mesmas. Para ela, em sua maior parte estas famílias têm estruturas frágeis, vivendo em uma situação constante de risco. São portadores de uma "subcidadania" e precisam ser auxiliados, orientados em suas ações. Complementando sua reflexão ela aponta para o fato de que talvez fosse necessário também, acompanhar as famílias dos internos durante o período da pena dos detentos já que serão elas a recebêlos, na maior parte das vezes, após o cumprimento da mesma.

Aqui está um ponto fundamental na justificação de suas ações e das formalidades exigidas pela instituição para a manutenção do contato com os internos. Tais atitudes funcionariam como uma espécie de processo educativo a estas famílias, como já apresentado anteriormente, para eles (operadores do sistema) a formalização das uniões, o reconhecimento da paternidade, a necessidade de se ser a/o responsável legal pelas crianças que fazem as visitas nos finais de semana específicos, enfim, a necessidade da 
formalização de todas as espécies de relação entre os internos e seus visitantes tem um caráter formativo num processo de acesso à cidadania. $\mathrm{O}$ documento formal é pensado como um passaporte para o ingresso ao mundo dos sujeitos de direitos. "começa por ai, tendo um documento nas mãos que diga que ela é mulher do sujeito, a mãe dos filhos dele, por exemplo, ela pode começar a procurar os direitos dela. Direitos que ela, muitas vezes, nem sabe que tem... mas que a gente tá aqui pra orientar."

Pergunto a eles se algum familiar já relatou dificuldades em conseguir reunir todos os documentos necessários para confeccionar a credencial e fazer as visitas e eles, tranquilamente respondem que escutam isto todos os dias. Relatam ainda que, algumas vezes, as conversas com os familiares, quando os mesmos vão levar os documentos, acabam tomando ares de terapia, as mães, esposas, irmãs - que segundo eles são as que mais procuram a central de credenciais - por vezes, vão relatando suas histórias de vida e de como chegaram até aqui. "é sempre muito sofrimento, muita pobreza e falta de estrutura familiar... algumas mães, principalmente dos reincidentes, dizem que não gostariam mais de fazer as visitas, mas não têm alternativa, os filhos estão aqui. E muitas vezes não é um filho só, são dois ou três. Tem delas que tem toda a família cumprindo pena, o pai e os filhos, todos no sistema...é sofrido por que elas se sentem responsáveis por eles, e de certa forma são mesmo... são responsáveis por eles aqui e por quando eles saírem... por isso é que eu te disse que as famílias são as que mais sofrem no sistema, sofrem ... sentem mais a pena do que os próprios internos."

Ao final a assistente reforça a sua tese de que estas famílias precisam ser amparadas para poderem receber novamente seus familiares que estiveram internados, precisam ser levadas "à cidadania", nas palavras dela. "cidadania mesmo, com direito a trabalho, educação, saúde, senão, todo o trabalho que a gente fizer aqui não vai ter resultado nenhum."

\section{Deus nos proteja da bondade alheia}

(ditado popular)

Não encontrei sempre, por parte do corpo técnico das instituições em que fiz pesquisa, posicionamentos tão simpáticos aos familiares dos detentos, devo admitir. Entretanto, não havia encontrado também, até aquele momento, técnicos que apontassem, 
claramente, que para além dos apenados era preciso acompanhar e ordenar o comportamento de seus familiares. Nas falas destes técnicos é possível perceber a presença de um forte traço de censura, tanto em relação ao sistema, quanto em relação aos familiares.

Durante a entrevista, a assistente social e seu colega embora realçassem o tempo inteiro serem solidários aos familiares dos internos, deixavam claro que as regras deveriam ser respeitadas e que o esforço feito no sentido de formalizar todas as relações era em benefício deles mesmos, já que, como dito pela própria assistente social, os familiares dificilmente tinha "sua vida em dia". Ter a vida em dia significava, para estes técnicos, portar todos os documentos, seguir as normativas relativas à identificação civil, passos necessários e fundamentais para o acesso e exercício da democracia plena. Em certa medida percebiam a fuga as regras como um dos elementos que os tornavam mais distanciados deste exercício. Agora, por conta de terem dentro do sistema um, ou mais de um de seus familiares, iriam, quisessem ou não, regularizar sua vida civil. Avançariam o primeiro degrau de sua institucionalização. A isto segue, como já vimos, o restante do processo.

Ao tomarem contato e serem institucionalizados estes indivíduos passam a ser classificados e localizados dentro da sociedade. Segundo Foucault (1970) as instituições são capazes de superar os pensamentos individuais e os adaptarem as formas e ao corpo de cada uma delas. Para ele, todas as instituições importantes na sociedade ocidental desenvolvem dinâmicas capazes de aprisionar mentes, corpos e corações em camisas de força poderosas. Embora não parta do pressuposto de que as instituições possuam uma personalidade própria que seja capaz de subsumir os sujeitos, aponta para o fato de que elas exercem sobre os mesmos uma intensa influência.

Douglas 1998, analisando o papel das instituições na sociedade, afirma que:

\footnotetext{
As instituições dirigem sistematicamente a memória individual e canalizam nossas percepções para formas compatíveis com as relações que elas autorizam. Elas fixam processos que são essencialmente dinâmicos, ocultam a influência que eles exercem e suscitam emoções relativas a questões padronizadas e que alcançam um diapasão igualmente padronizado. Acrescente-se a tudo isso que as instituições revestem-se de correção e agem no sentido de que sua mútua corroboração flua por todos os níveis de nosso sistema de informação. (DOUGLAS, 1998, p. 109)
} 
Ainda segundo esta autora, as instituições, ao classificarem os indivíduos, fornecem elementos para sua localização na sociedade e como são consideradas legítimas a marcação a qual sujeita os indivíduos também o é. Sendo assim, a autora pergunta: Como é possível pensarmos sobre nós mesmos na sociedade a não ser usando as classificações estabelecidas em nossas instituições? (DOUGLAS, 1998. p118).

Ao marcarem e localizarem os indivíduos acabam engendrando sua construção como pessoas e, sequencialmente criam também o padrão de seu comportamento. Para Douglas: "Trata-se de um processo muito mais dinâmico, pelo qual nomes são enunciados e, sem demora, emergem novas criaturas que a eles correspondem”. (1998. p 119). Sendo assim, uma vez instituídos, fugir a marca é bastante difícil.

Retorno assim a fala da assistente social. Embora demonstre simpatia para com os familiares, sugere que as mesmas também necessitariam de cuidados. Se em momento anterior a assistente social aponta para o fato de os agentes penitenciários colocarem os internos e seus familiares no mesmo patamar e explica assim o comportamento agressivo por parte dos agentes, parece usar a mesma lógica em seu raciocínio ao sugerir tal ação.

Em sua fala acaba colocando também os familiares sob suspeita e insinua que os mesmos têm em seus comportamentos falhas, senão morais, cívicas certamente. A regulamentação da situação civil, expressa por meio da certificação formal das relações de parentesco parece ser apontada como início do caminho de recuperação para a situação familiar, situação esta que ela, em alguns momentos, adjetivou de desestruturada. Assim, a reforma moral pressuposta aos internos da instituição deveria alcançar também, de acordo com ela, seus familiares, já que ao saírem da prisão os ex-internos retornarão ao ambiente que antes os havia levado ao crime.

É bastante provável que essa postura com relação aos familiares dos internos esteja ligada - fato apontado por ela durante a entrevista - a presença e atuação das facções tanto sobre os internos ao sistema, quanto seus familiares. Preocupada com a violência a que são submetidos os familiares, acaba propondo que os cuidados desta instituição sistema penitenciário- atinjam também os familiares. Entretanto, parece não atentar para o fato de que as famílias estão submetidas às facções por estarem, antes, submetidas ao sistema penitenciário e que, portanto, de alguma forma, a instituição de que fazem parte tem responsabilidade neste processo. 
Revista NEP, Núcleo de Estudos Paranaenses, Curitiba, v.4, n.2, dez. 2018

Interessante notar que apesar de declarar um posicionamento marcadamente diferenciado com relação aos agentes penitenciários, a assistente social acaba acionando uma representação muito próxima a deles acerca dos familiares dos internos. Tanto eles - agentes -, quanto ela - assistente - ressaltam o fato de sentirem empatia pelos familiares e serem solidários com sua situação. Mas parecem acreditar, entretanto, que os mesmos necessitam em seu tratamento de uma postura firme e que reforce sempre as regras e normativas da instituição. Claramente parecem duvidar que esses sujeitos sejam portadores de autonomia moral, necessitando por isso, da tutela da instituição para adequarem seus comportamentos. Convém lembrar ainda, que em sua fala deixa claro pensar os técnicos e os familiares em posicionamentos diferenciados também na esfera jurídica. Se percebe a entrada de coisas não permitidas dentro do sistema como preocupante e desorganizadora da ordem e que, portanto, deve ser evitada a qualquer custo (e o custo aqui é, na maior parte das vezes, a dignidade dos familiares dos internos), não consegue pensar que as consequências do descumprimento da regra de proibição devam ser as mesmas para todos que sejam flagrados portando as tais coisas proibidas. É assim que naturaliza o descumprimento desta norma quando ele se dá por algum dos técnicos do sistema. Para ela, esta é uma falha de menor valor, são apenas funcionários corruptos a serem desligados do sistema, o mesmo peso e medida não são aplicados caso os familiares sejam os burladores da norma. Para estes, flagrante, processo e prisão são a sequência natural.

Acredito que, de certa maneira, a entrada para a instituição firma suas marcas em todos os seus internos. Da equipe dirigente aos internos compulsórios, cada um e todos passam por processos de institucionalização de forma a acabarem tendo o mesmo discurso, embora para cada segmento este discurso possa apresentar tons diferenciados. Pouco posso falar acerca dos internos, visto que nesta pesquisa não entrei em contato com os mesmos. Entretanto, no tocante aos familiares e aos técnicos penso ter conseguido demonstrar que há certo consenso em suas falas.

As falas dos familiares são permeadas por um sentimento de responsabilidade pelos atos de seus parentes presos, afinal, se a função familiar houvesse sido bem desempenhada nenhum deles estaria nesta situação e, é por isso que se submetem a serem institucionalizados, marcados, estigmatizados, localizados e hierarquizados dentro da instituição e da sociedade. 
Por parte do corpo técnico (sejam os assistentes sociais, agentes penitenciários ou mesmo diretores de unidades), há também o reconhecimento da responsabilidade dos familiares com seus parentes internos, reconhecimento que eles declaram de forma ambígua ou talvez polissêmica. Por um lado utilizam esta responsabilização chamandoos a manterem os laços familiares - que como vimos é essencial para a manutenção do equilíbrio interno do sistema - e por outro estendem para os parentes a responsabilidade pelo ato cometido pelos internos, visto não terem cumprido a função de educá-los convenientemente para o convívio social e não ter dado conta de introjetar nestes sujeitos às normas e regras da que regem a sociedade.

\section{Bibliografia}

COELHO, Edmundo Campos. A oficina do Diabo e outros estudos sobre a criminalidade. R.J/ S.P: Editora Record, 2005.

DOUGLAS, Mary. Como as instituições pensam. São Paulo: EDUSP, 1998.

DURKHEIM, E. Os Pensadores. São Paulo: Abril Cultural, 1983.

EVANGELISTA, Maria D. R. Prisão Aberta: Volta à Sociedade. São Paulo: Cortez, 1983.

FOUCAULT. MICHEL. Microfísica do Poder. Rio de Janeiro: Edições Graal.1979.

A ordem do discurso. 9. ed. São Paulo: Loyola, 2003.

História da Loucura na Idade Clássica. São Paulo: Perspectiva, 1978.

GONÇALVES, Pedro Correia. A era do humanitarismo penitenciário, In: Revista da Faculdade de Direito, UFG, v.33, n1, jan-jun 2009.

MORAES, Pedro Rodolfo Bodê de. Punição, encarceramento e construção de identidade profissional entre agentes penitenciários. São Paulo: IBCCRIM, 2005.(Monografias, 33).

QUINTINO, Silmara AP. Creche na prisão feminina do Paraná- humanização da pena ou intensificação do controle social do Estado? Dissertação de mestrado do Curso de Pós-Graduação em Sociologia - UFPR, 2005. 
SHELLA, Julia Alves F. Preso, prisão e reabilitação: a visão das assistentes sociais do departamento penitenciário do Estado do Paraná. Dissertação de Mestrado do Programa de Pós-Graduação em Sociologia da UFPR, 2007.

RAMALHO, José Ricardo. O mundo do crime: a ordem pelo avesso. Rio de Janeiro: Graal, 1979.

SILVA, Valter Cardoso. A Educação atrás das grades: representações de Tecnologia e Gênero entre adultos presos. Dissertação de Mestrado - PPGTE -Programa de Pósgraduação em Tecnologia - UTFPR - 2006.

Recebido: 10 set. 2018

Aceito: 16 nov. 2018 